Für eine Philosophie von Freiheit und Streit 
Günter Figal

\title{
Für eine Philosophie von Freiheit und Streit
}

\author{
Politik, Ästhetik, Metaphysik
}

Verlag J.B. Metzler Stuttgart. Weimar 
Die Deutsche Bibliothek - CIP-Einheitsaufnahme

Figal, Günter:

Für eine Philosophie von Freiheit und Streit:

Politik,Ästhetik, Metaphysik / Günter Figal. - Stuttgart; Weimar:

Metzler, 1994

ISBN 978-3-476-01204-3

ISBN 978-3-476-03537-0 (eBook)

DOI 10.1007/978-3-476-03537-0

Dieses Werk einschließlich aller seiner Teile ist urheberrechtlich geschützt. Jede Verwertung außerhalb der engen Grenzen des Urheberrechtsgesetzes ist ohne Zustimmung des Verlages unzulässig und strafbar. Das gilt insbesondere für Vervielfältigungen, Übersetzungen, Mikroverfilmungen und die Einspeicherung und Verarbeitung in elektronischen Systemen.

(c) 1994 Springer-Verlag GmbH Deutschland Ursprünglich erschienen bei J.B. Metzlersche Verlagbuchhandlung und Carl Ernst Poeschel Verlag GmbH in Stuttgart 1994 


\section{Inhalt}

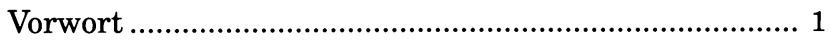

I. Vom Schweigen der Texte.

$\mathrm{Zu}$ einem hermeneutischen Begriff der Interpretation

II. Versuch über die Freiheit.

Ontologische Überlegungen in praktischer Absicht

III. Der Intensitätsgrad des Politischen.

Carl Schmitts Phänomenologie der Feindschaft

und das Ende des ideologischen Weltbürgerkriegs

IV. Die Zwischen-Zeit der Modernität.

Europa und die Vaterländer, Nihilismus

und Selbstverstehen in Nietzsches Perspektive 56

V. Typos und Nuance.

Entgrenzte und begrenzte Ästhetik mit Nietzsche

VI. Stereoskopische Erfahrung.

Ernst Jüngers Poetik des abenteuerlichen Herzens

VII. Ästhetische Erfahrung der Zeit.

Adornos Avantgardismus und Benjamins Korrektur

VIII. Geschichte als Geschick und die Präsenz der Geschichte.

Zur Bestimmung der Philosophie mit und ohne Hegel .... 130 
IX. Letzte Götter.

Hermeneutische Theologie bei Nietzsche und Heidegger

X. Das absolut Besondere.

Individualität und Religion nach Kierkegaard 166

Nachweise 181 